\title{
AN INTER-HEMISPHERIC VOLCANIC TIME-MARKER IN ICE CORES FROM GREENLAND AND ANTARCTICA
}

\author{
by \\ C.C. Langway, Jr \\ (Department of Geological Sciences, State University of New York at Buffalo, \\ 4240 Ridge Lea Road, Amherst, NY 14226, U.S.A.) \\ and \\ H.B. Clausen and C.U. Hammer \\ (Department of Glaciology, Geophysical Institute, University of Copenhagen, \\ Haraldsgade 6, DK - 2200 Copenhagen N, Denmark)
}

\begin{abstract}
A strong volcanic-acid signal is clearly registered, using an acidity-measuring technique, in the A.D. 1259 ice layer in four different Greenland ice cores (Camp Century, Milcent, Crête and Dye 3). This signal is similar in amplitude to the Laki (Iceland) A.D. 1783 volcanic event as recorded in the central and south Greenland ice cores. Measurement of ice layers from corresponding age levels in Antarctic ice cores (Byrd Station, South Pole and J-9 on the Ross Ice Shelf) provides similar strong acid signals. There is no historical record of a significant volcanic eruption for the period around A.D. 1260 in the Northern Hemisphere. Subsequent chemical analyses of all A.D. 1259 ice layers show similar compositions. We suggest that the A.D. 1259 signals registered in both Greenland and Antarctica were caused by the same volcanic disturbance and that its epicenter was located at the Earth's equatorial zone, which enabled global distribution of the acid gases. These results indicate that inter-hemispheric dating of ice sheets is possible by the chemical identification of major eruptive volcanic events in the equatorial zone.
\end{abstract}

\section{INTRODUCTION}

Establishing a depth-age relationship is an important first step in the fuller examination of an ice core. Until the core is dated it is not possible to interpret meaningfully the wealth of important paleo-environmental proxy data contained in the stratigraphic layers of ice sheets. Certain limitations exist in the dating of ice cores from both Greenland and Antarctica. The difficulties are related to the varying environmental conditions which existed at the original snow-deposit sites and to the post-depositional changes occurring there and along the flow-line trajectory leading to the drilling site. In many cases it is less difficult to date Greenland ice cores than, for instance, Antarctic ice cores (Langway and others 1985). The most successful primary methods for dating long ice cores have been the oxygen-isotope and the "acidity" measurement techniques, which are most accurate when performed in parallel (Hammer and others 1986). Both methods rely on unbroken, connected ice cores and continuous measurements, and they have been used to date ice cores back $10^{3}-10^{4}$ years B.P.

We present here results of a successful attempt to cross-correlate a single, significant volcanic event in the thirteenth century, as a chemical signal recorded and measured from the same stratigraphic time units in both polar ice sheets.

\section{SAMPLES}

Two sets of ice-core samples were used in this study. The first set was from the Greenland locations of Camp Century, Milcent, Crête and Dye 3. The other set was from the Antarctic locations of Byrd Station, South Pole and J-9 (on the Ross Ice Shelf). Table I lists details of samples and collection sites.

The Camp Century ice core was augered to the $500 \mathrm{~m}$ depth using a thermal coring device, and thereafter to bedrock - at about the $1400 \mathrm{~m}$ depth-using an electromechanical drill (Ueda and Garfield 1968). Core drilling took place between 1961 and 1966. This was the first continuous ice-core drilling operation to reach bedrock from an inland polar-ice sheet location. Although spot sampling and physical measurements were performed on the ice core in the field, it was not dated by any method until after

TABLE I. SAMPLE AND SITE IDENTIFICATION FOR GREENLAND AND ANTARCTICA.

$\begin{array}{llcrrrrc}\text { Site } & \text { Lat. } & \text { Long. } & \begin{array}{c}\text { Elevation } \\ \text { m above } \\ \text { sea-levcl }\end{array} & \begin{array}{l}\text { Year } \\ \text { core } \\ \text { drilled }\end{array} & \begin{array}{l}\text { Depth } \\ 1259 \\ \text { event } \\ \mathrm{m}\end{array} & \begin{array}{l}\text { Annual } \\ \text { mean } \\ \text { temp. } \\ { }^{\circ} \mathrm{C}\end{array} & \begin{array}{l}\text { Annual mean } \\ \text { rate of } \\ \text { accumulation } \\ \text { m of ice }\end{array} \\ \text { Camp Century } & 77.17^{\circ} \mathrm{N} & 61.13^{\circ} \mathrm{W} & 1880 & 1963 & 263.6 & -24 & 0.38 \\ \text { Crête } & 71.12^{\circ} \mathrm{N} & 37.32^{\circ} \mathrm{W} & 3170 & 1974 & 220.4 & -30 & 0.28 \\ \text { Milcent } & 70.30^{\circ} \mathrm{N} & 44.58^{\circ} \mathrm{W} & 2410 & 1973 & 364.5 & -22 & 0.53 \\ \text { Dye 31971 } & 65.18^{\circ} \mathrm{N} & 43.49^{\circ} \mathrm{W} & 2480 & 1971 & 363.6 & -20 & 0.54 \\ \text { Dye 31980 } & 65.18^{\circ} \mathrm{N} & 43.49^{\circ} \mathrm{W} & 2480 & 1980 & 369.9 & -20 & 0.54 \\ \text { Byrd J-9 } & 80.02^{\circ} \mathrm{S} & 119.52^{\circ} \mathrm{W} & 1530 & 1968 & 97.8 & -28 & 0.11 \\ \text { RISP J-9 } & 82.38^{\circ} \mathrm{S} & 168.63^{\circ} \mathrm{W} & 55 & 1976 & 85.4 & -27 & 0.10 \\ \text { South Pole } & 90.00^{\circ} \mathrm{S} & & 2835 & 1978 & 87.8 & -49 & 0.08\end{array}$


transport back to the laboratory. The core was augered by two different experimental drilling systems, which caused several sections of the core profile to be fragmented, discontinuous or lost during drilling. The physical condition of the core compounded the difficulties of dating the ice, but it was on this core that the original continuous $\delta^{18} \mathrm{O}$ dating method for ice cores was developed (Dansgaard and others 1971).

The Holocene ice in this core was dated by reference to seasonal $\delta^{18} \mathrm{O}$ and dust variations (Hammer and others 1978). At selected depths, d, the mean annual layer thickness $\lambda_{y}$ ( $m$ of ice equivalent / year) was determined by counting seasonal variations over an ice-core increment of the length dy. The age $t$ at the depth $d=H-y(H$ is the ice thickness, $y$ is the distance from the bottom) is:

$$
t=\int_{y}^{H} \frac{d y}{\lambda_{y}}
$$

This time-scale for the Camp Century core was later refined and fixed at certain depths, such as the historically recorded large Icelandic volcanic eruptions of Laki (A.D. 1783) and Eldja (A.D. 934), by using a solid electricalconductivity method, ECM (Hammer 1980).

The Milcent ice core was augered to the $398 \mathrm{~m}$ depth during the summer of 1973, using a thermal-coring device. The core was dated only by counting annual variations in the continuously measured series of $\delta^{18} \mathrm{O}$. The Milcent core exhibits the best example of $\delta^{18} \mathrm{O}$ seasonals yet measured. This is mainly due to the site location's relatively high rate of accumulation ( $53 \mathrm{~cm}$ of ice equivalent per year) and relatively low mean annual surface temperature $\left(-22^{\circ} \mathrm{C}\right)$. The high accumulation rate allows the annual $\delta^{18} \mathrm{O}$ oscillations to survive the active diffusion process which occurs during firnification, and the low surface temperature prevents extensive melting during the summer. The ice at the bottom of the core has been dated as A.D. 1176 .

The Crête ice core was augered to the $404 \mathrm{~m}$ depth during the summer of 1974, also using a thermal-coring device. The core was dated by counting annual variations in the continuously measured series of $\delta^{18} \mathrm{O}$ and by a later application of the ECM method. For certain sections of the core, dust measurements and nitrate-concentration levels were used to demarcate limits of annual cycles. The Crête location is almost ideal for obtaining paleo-environmental proxy data and therefore serves as our Greenland reference core for the past 1400 years. The ice at the bottom of the core has been dated as A.D. 553 .

Two ice cores were obtained at Dye 3. The first was recovered in 1971, to a depth of $372 \mathrm{~m}$, using a thermal-coring device. The second core was augered to bedrock, at $2037 \mathrm{~m}$, during the Greenland Ice Sheet Program (GISP) 1979-81 field operations, using a newly designed and constructed Danish drill (Gundestrup and others 1984). The 1971 core was dated by continuous $\delta^{18} \mathrm{O}$ measurements, and the $1979-81$ core was dated by continuous $\delta^{18} \mathrm{O}$ measurements, the ECM method and dust measurements. The annual $\delta^{18} \mathrm{O}$ cycles are not as regular as those from Milcent because penetration and refreezing of melt water offsets the advantages of the high annual rate of accumulation $(53 \mathrm{~cm}$ of ice equivalent per year) and the low mean annual surface temperature $\left(-20^{\circ} \mathrm{C}\right)$.

The Byrd Station ice core was augered to bedrock, at $2164 \mathrm{~m}$, during the 1967-68 field seasons, using the same electro-mechanical drill as at Camp Century (Ueda and Garfield 1969). This was the first ice-core drilling to reach bedrock in Antarctica.

The South Pole ice core was augered to $100 \mathrm{~m}$ in 1978 and the J-9 core to $100 \mathrm{~m}$ during the 1975-76 Ross Ice Shelf Project (RISP) field seasons, both cores were augered by electro-mechanical drills. Dating details for these cores are discussed in the next section.

\section{RESULTS AND DISCUSSIONS}

\section{The A.D. 1259 acid layer}

Large volcanic eruptions are in general connected with the release of great amounts of strong acid gases into the atmosphere. The composition and amount of these gases vary with time and are of ten deposited as strong acids such as $\mathrm{H}_{2} \mathrm{SO}_{4}, \mathrm{HCl}$ and $\mathrm{HF}$ on the polar ice-sheet surfaces in an amount related to the violence and extent of the eruption. Other factors which influence the composition and amount of volcanic acids are the chemical nature of the eruption and the distance to the ice sheet. These acid layers are identified in ice cores as peaks in the electrical-conductivity records and can be detected by a solid ECM, as discussed by Hammer (1980).

Acid signals from major volcanic eruptions in Iceland and from violent eruptions south of $50^{\circ} \mathrm{N}$ are clearly present in snow deposits all over Greenland (Hammer 1984). In the $400 \mathrm{~m}$ deep Crête core, the third-largest acid signal recovered (Fig.1) was detected in the A.D. 1258-59 layer (Hammer and others 1980). In both Dye 3 cores (Fig.2), a large acid signal was found in the A.D. 1258-59 layers. This signal is among the largest in the Holocene Dye 3 acidity record. In the Milcent core (Fig.3), a large acid signal was found in the layer dated A.D. 1259 by counting $\delta^{18} \mathrm{O}$ oscillations downwards from the top. In the Camp Century core (Fig.4), a large acid signal was detected in an ice layer dated to about A.D. 1250. This signal is among the largest found for the entire Holocene record of Camp Century.

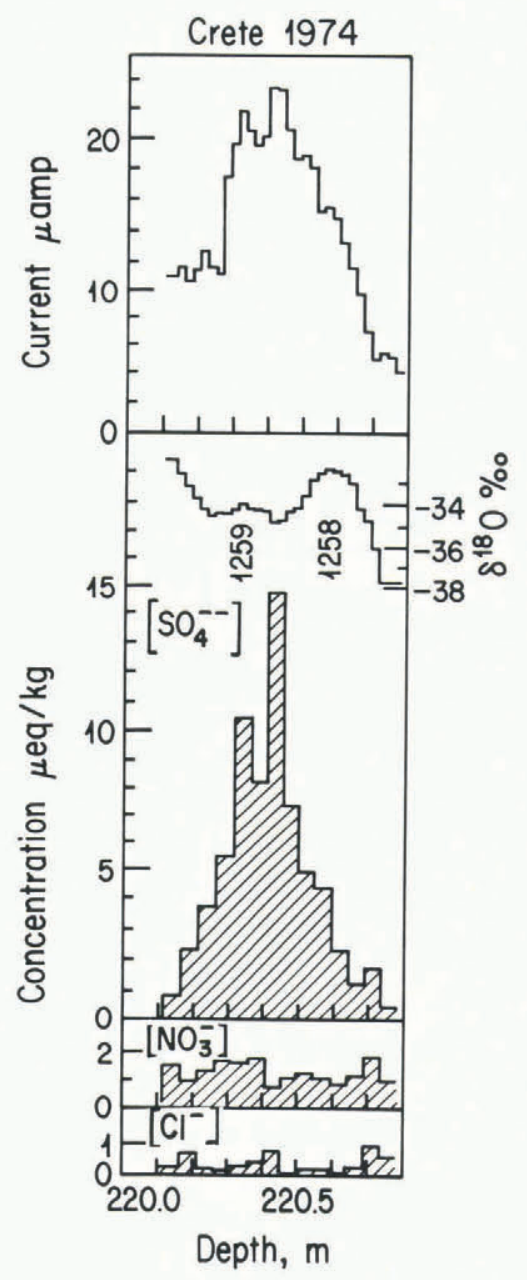

Figs.1 -9 . Title at top refers to the site (Greenland and Antarctica) and the year the core was drilled. Figures $1-6$ and 9 show on a depth scale in $\mathrm{m}$ below the surface the anion concentrations (shaded curves) of $\mathrm{Cl}^{-}, \mathrm{NO}_{3}^{-}$and $\mathrm{SO}_{4}{ }^{2-}$ in $\mu$ equivalents per $\mathrm{kg}$ of ice $(\mu \mathrm{eq} / \mathrm{kg})$ from the A.D. 1259 event in the ice samples. Figures 7 and 8 exhibit the anion concentrations at South Pole for the Krakatoa (A.D. 1883) and Tambora (A.D. 1815) eruptions respectively. Figures $1-3$ show the seasonal variation of $\delta^{18} \mathrm{O}$ in per mille (scale to the right). The top curve in Figures $1 \rightarrow$ (except for Fig.4, see text), shows the electrical current in $\mu \mathrm{amp}$, determined by the ECM at $-14^{\circ} \mathrm{C}$. This method serves here to identify the exact position of the high volcanic-acid layer in the core. 

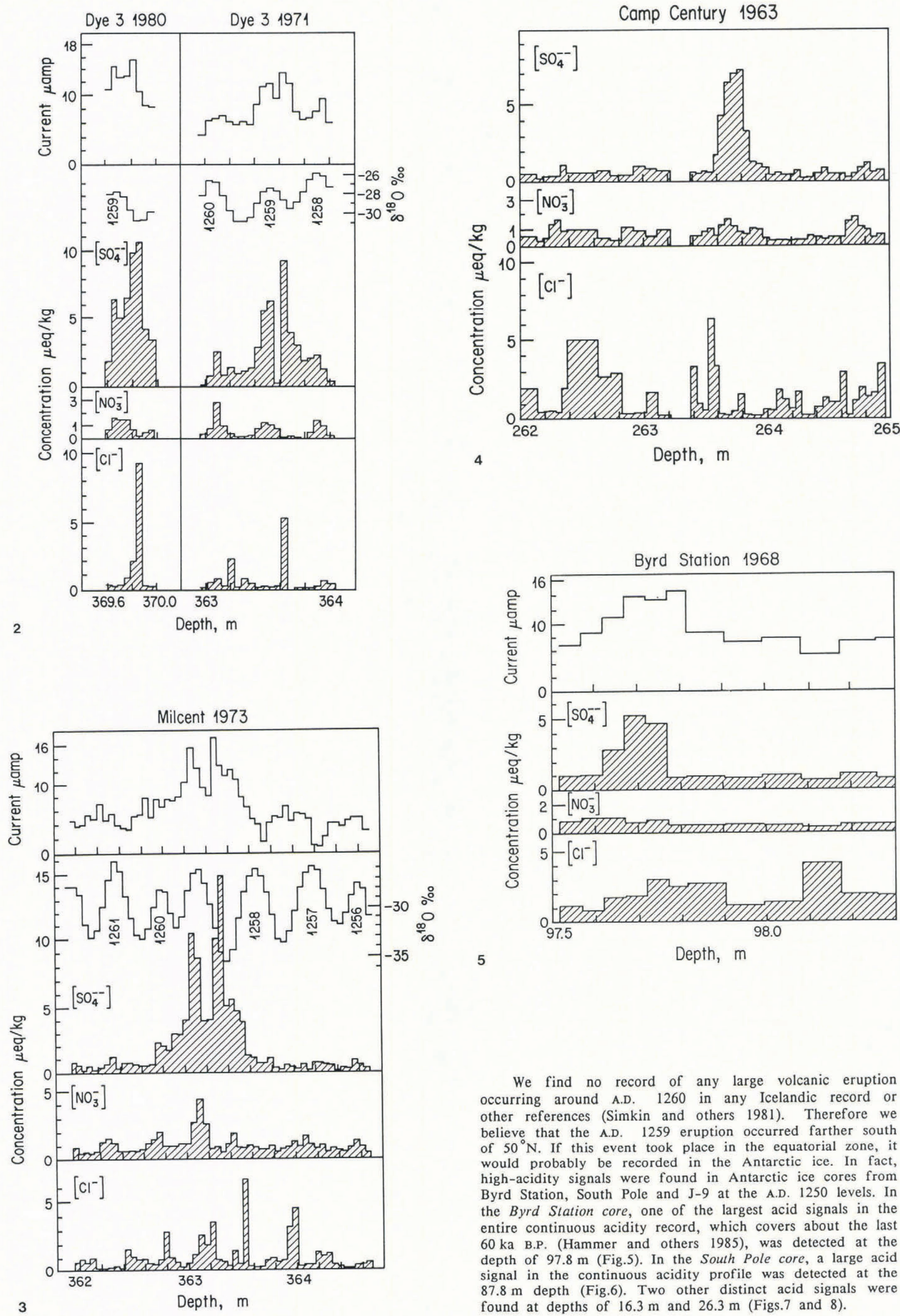

We find no record of any large volcanic eruption occurring around A.D. 1260 in any Icelandic record or other references (Simkin and others 1981). Therefore we believe that the A.D. 1259 eruption occurred farther south of $50^{\circ} \mathrm{N}$. If this event took place in the equatorial zone, it would probably be recorded in the Antarctic ice. In fact, high-acidity signals were found in Antarctic ice cores from Byrd Station, South Pole and J-9 at the A.D. 1250 levels. In the Byrd Station core, one of the largest acid signals in the entire continuous acidity record, which covers about the last 60 ka B.P. (Hammer and others 1985), was detected at the depth of $97.8 \mathrm{~m}$ (Fig.5). In the South Pole core, a large acid signal in the continuous acidity profile was detected at the $87.8 \mathrm{~m}$ depth (Fig.6). Two other distinct acid signals were found at depths of $16.3 \mathrm{~m}$ and $26.3 \mathrm{~m}$ (Figs.7 and 8). 

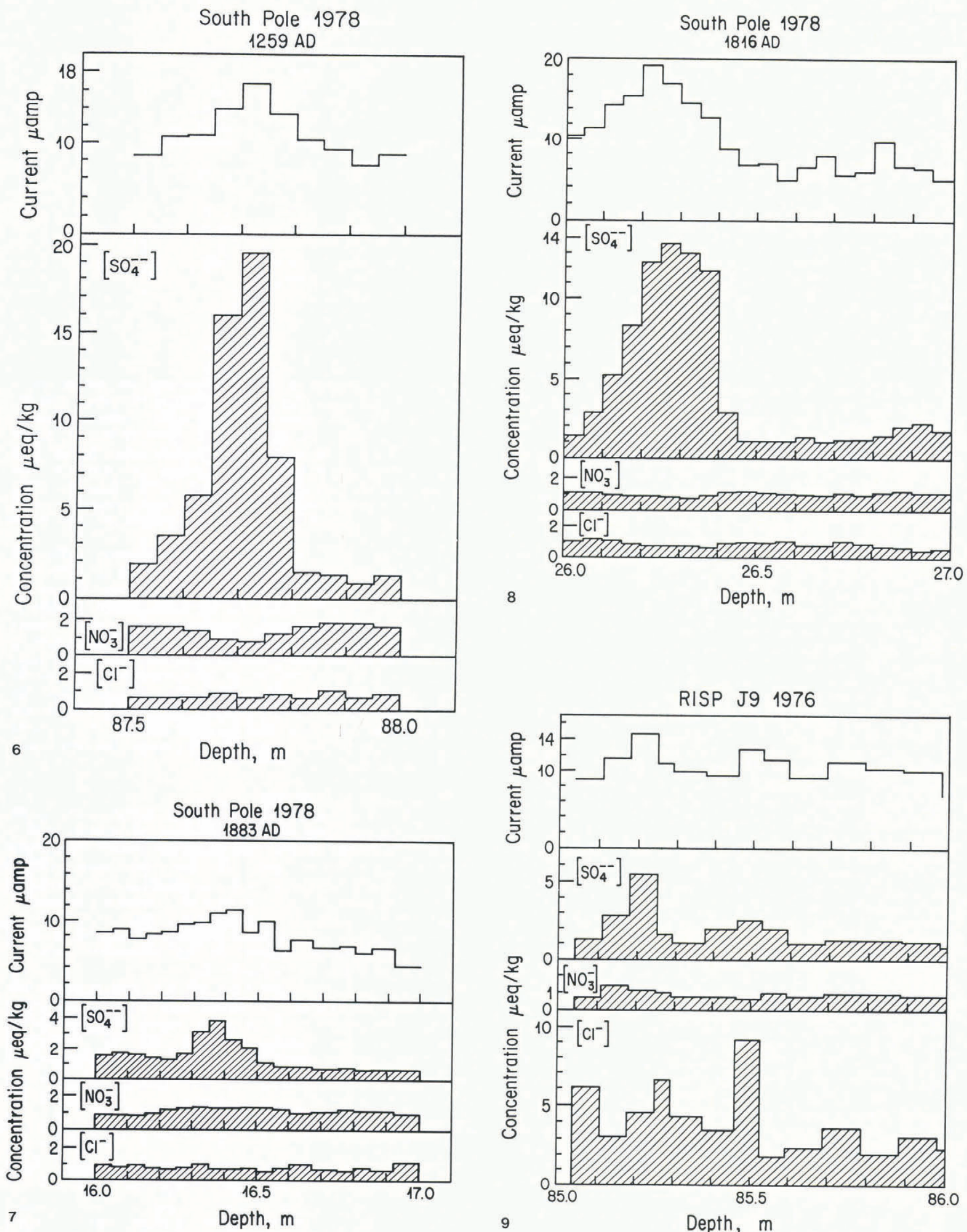

Between the depth interval $70-95 \mathrm{~m}$ in the $J-9$ core, the largest acidity signal measured was detected at a depth of $85.2 \mathrm{~m} \mathrm{(Fig.9).} \mathrm{Due} \mathrm{to} \mathrm{the} \mathrm{relatively} \mathrm{low} \mathrm{rate} \mathrm{of}$ accumulation at the Antarctic locations included in this study, seasonal $\delta^{18} \mathrm{O}$ variations do not survive the diffusion processes during densification of the firn. Table II contains the calculated ages of the acid layers for the Antarctic

stations, assuming a uniform vertical strain-rate for all sites. Schwander (unpublished) found similar distinct acid layers at comparable depth in another ice core from the South Pole. Zanolini and others (1985) report that the largest acidity and sulfate peak found in a $200 \mathrm{~m}$ ice core from Terre Adélie could be due to a powerful volcanic eruption some 600 years ago. This powerful eruption is probably the 
TABLE II. ACID-LAYER DEPTHS AND AGES FOR ANTARCTIC SITES.

\begin{tabular}{|c|c|c|c|c|c|c|c|}
\hline \multirow[b]{2}{*}{ Site } & \multirow{2}{*}{$\begin{array}{l}\text { Depth of } \\
\text { acid layer } \\
m \text { of snow }\end{array}$} & \multirow{2}{*}{$\begin{array}{l}\mathrm{d} \text {, Depth of } \\
\text { acid layer } \\
\mathrm{m} \text { of ice } \\
\text { equivalent }\end{array}$} & \multirow{2}{*}{$\begin{array}{l}\mathrm{m} \text { of } \\
\text { air }\end{array}$} & \multirow{2}{*}{$\begin{array}{l}\mathrm{H} \text {, ice } \\
\text { thickness } \\
\mathrm{m} \text { of ice } \\
\text { equivalent }\end{array}$} & $\begin{array}{l}\text { Age } \\
t=\frac{H}{\lambda}\end{array}$ & $\begin{array}{l}\text { years } \\
\frac{\mathrm{H}}{\mathrm{H}-\mathrm{d}}\end{array}$ & \multirow{2}{*}{$\begin{array}{l}{ }^{\lambda} \mathrm{H}, \\
\text { annual } \\
\text { m of ice } \\
\text { equivalent }\end{array}$} \\
\hline & & & & & B.P. & A.D. & \\
\hline J-9 & 85.2 & 70.1 & 15.1 & 400 & 786 & 1190 & 0.098 \\
\hline $\begin{array}{l}\text { Byrd } \\
\text { Station }\end{array}$ & 97.8 & 78.8 & 19.0 & 2164 & $\begin{array}{l}669 \\
730\end{array}$ & $\begin{array}{l}1299 \\
1238\end{array}$ & $\begin{array}{l}0.12 \\
0.11\end{array}$ \\
\hline $\begin{array}{l}\text { South } \\
\text { Pole }\end{array}$ & $\begin{array}{l}87.8 \\
26.2 \\
16.3\end{array}$ & $\begin{array}{r}57.6 \\
13.7 \\
8.0\end{array}$ & $\begin{array}{r}30.2 \\
12.5 \\
8.3\end{array}$ & 3000 & $\begin{array}{r}646 \\
153 \\
89\end{array}$ & $\begin{array}{l}1332 \\
1825 \\
1889\end{array}$ & 0.09 \\
\hline
\end{tabular}

A.D. 1259 event. Fisher and Koerner (1988, this volume) found one of the largest acid signals in the Holocene acidity record of an Ellesmere Island ice core at a depth corresponding to a date of A.D. 1259.

The snow depths in Table II are converted into meters of ice equivalent, using measured density profiles from South Pole (Chiang and Langway 1978), from Byrd Station (Bender and Gow 1961) and from J-9 (Langway 1976). The annual rate of accumulation in meters of ice equivalent per year at South Pole is $0.09 \mathrm{~m}$ (Lambert and others 1977), at Byrd Station it is between $0.12 \mathrm{~m}$ (Gow and others 1972) and $0.11 \mathrm{~m}$ (Hammer and others, in preparation) and at J-9 it is $0.098 \mathrm{~m}$ (Clausen and Dansgaard 1977).

The acidity profile for the Byrd Station core exhibits seasonal variations thousands of years beyond the Holocene/ Wisconsin transition, which is about 11 ka B.P. (Hammer and others 1985). Since the upper $88 \mathrm{~m}$ of the Byrd Station core are missing, we have only the calculated age for the acid layer at $97.8 \mathrm{~m}$. As can be seen from Table II, a date of A.D. 1259 for this acid event agrees well with the $1238-99$ range for the calculated ages.

The South Pole acidity profile is difficult to interpret in terms of seasonal variations, due to the low rate of accumulation at this site. From accumulation-rate studies of the Ross Ice Shelf (Clausen and Dansgaard 1977), we know it is difficult to apply the method of visible stratigraphy to dating ice cores from regions with a low annual rate of accumulation. Mosley-Thompson and Thompson (1982) dated a $104 \mathrm{~m}$ South Pole core (drilled in 1974) by counting microparticle oscillations, but concluded that as many as 90 years may be missing from the record, due to wind erosion and lack of precipitation. If we apply their time-scale to the three acid signals we find at the $16.3,26.2$ and $87.8 \mathrm{~m}$ depths, we obtain the years 1887, 1812, and 1216 respectively. Although there is a 4 year span between the drillings, and some distance between the cores, the ages we arrived at strongly indicate that these acid signals are the volcanic "footprints" of Krakatoa (A.D. 1883), Tambora (A.D. 1815) and the "A.D. 1259 event" respectively, and only about 40 years of accumulation are missing or poorly represented in the last 700 years of precipitation at the South Pole.

Using $0.098 \mathrm{~m}$ of ice equivalent/year for the present annual mean rate of accumulation at $\mathrm{J}-9$, we calculate the $85.2 \mathrm{~m}$ depth as being 786 years old, or about $10 \%$ older than it should be if it represents A.D. 1259. In other words, the age may have been overestimated by 69 years, or $10 \%$, due to changes in the accumulation rate, which would account for the difference. Since this is the largest acid signal in the 250 year depth interval we measured, we take this peak as representing A.D. 1259.

\section{Anion composition}

Increments of the ice cores at depth intervals around the acidity peaks were measured for $\mathrm{SO}_{4}{ }^{2-}, \mathrm{NO}_{3}{ }^{-}$and $\mathrm{Cl}^{-}$ concentrations by ion chromatography in the Ice Core Laboratory at the State University of New York at Buffalo. The results are shown in Figures $1-9$, where the concentrations are given in $\mu$ equivalent per $\mathrm{kg}(\mu \mathrm{eq} / \mathrm{kg})$. Sulfate is the dominant anion in all acid layers. The nitrate content shows an average of around $1 \mu \mathrm{eq} / \mathrm{kg}$, with little variation from year to year, even during the deposition of the volcanic acid. The chloride content of these samples shows some well-known trends of higher concentrations at coastal and lower-altitude sites (J-9, Byrd Station and Camp Century) and a decrease inland towards high-altitude sites (South Pole and Crête). These findings are consistent with other studies (Herron and others 1977, Boutron 1979, Herron and Langway 1979, Herron 1982, Rasmussen and others 1984, Finkel and others 1986, Mayewski and others 1986).

In this study, the ECM method (Hammer 1980) was merely used to identify high acid signals, and no calibration by liquid $\mathrm{pH}$ measurements was performed to convert the electrical currents in $\mu \mathrm{amp}$ into $\mathrm{H}^{+}$concentration. In Figures $1 \rightarrow$ (but not Fig.4, Camp Century) the top curve shows measured currents in $\mu \mathrm{amp}$ at $-14^{\circ} \mathrm{C}$. For Camp Century, a very thin sample that had been stored for over 20 years was measured by ECM. Hence the current level cannot be compared directly to the current values obtained from the other cores; however, a clear increase in the current was observed in the depth interval $263.6-263.8 \mathrm{~m}$. The seasonal variations in $5^{18} \mathrm{O}$ are shown for the three Greenland sites also in Figures 1-3.

\section{Volcanic $\mathrm{H}_{2} \mathrm{SO}_{4}$ deposition}

On the basis of the measured sulfate-concentration levels, we calculated the deposition rate of volcanic $\mathrm{H}_{2} \mathrm{SO}_{4}$, which is defined as the area above the general background in Figures $1-9$. Table III lists the mean sulfate concentrations (column 2) over the length of ice (column 5) which represents the period of volcanic deposition, background sulfate concentrations (bg, column 3), volcanic-sulfate concentrations (column 4), deposition rates of volcanic sulfate (column 6) and desposition rates of volcanic sulphuric acid (column 7).

The $\mathrm{H}_{2} \mathrm{SO}_{4}$ deposition from the A.D. 1259 eruption was 117 and $90 \mathrm{~kg} / \mathrm{km}^{2}$ at Crête and South Pole (SP) respectively, and is of the same order of magnitude as given for the Tambora eruption $\left(69\right.$ and $83 \mathrm{~kg} / \mathrm{km}^{2}$ respectively). For comparison, the Icelandic eruption of Laki

TABLE III. SULFATE DEPOSITION RATES

\begin{tabular}{|c|c|c|c|c|c|c|}
\hline Milcent & $\mu \mathrm{eq} / \mathrm{kg}$ & $\mu e q / \mathrm{kg}$ & $\mu \mathrm{eq} / \mathrm{kg}$ & $\mathrm{m}$ of ice & $\mathrm{meq} / \mathrm{m}^{2}$ & $\mathrm{H}_{2} \mathrm{SO}_{4}$ \\
\hline 1 & 2 & 3 & 4 & 5 & 6 & 7 \\
\hline Site & $\begin{array}{l}\text { Mean } \\
\mathrm{SO}_{4}{ }^{2-} \\
\mu \mathrm{eq} / \mathrm{kg}\end{array}$ & $\begin{array}{l}\mathrm{SO}_{4}{ }^{2-} \\
\mathrm{bg}^{2} \\
\mu \mathrm{eq} / \mathrm{kg}\end{array}$ & $\begin{array}{l}\mathrm{SO}_{4}{ }^{2-} \\
\text { volc. } \\
\mu \mathrm{eq} / \mathrm{kg}\end{array}$ & $\begin{array}{l}\text { Length } \\
\text { of event } \\
\mathrm{m} \text { of ice }\end{array}$ & $\begin{array}{l}\text { Dep. } \\
\mathrm{SO}_{4}{ }^{2-} \\
\mathrm{meq} / \mathrm{m}^{2}\end{array}$ & $\begin{array}{l}\text { Dep. } \\
\mathrm{H}_{2} \mathrm{SO}_{4} \\
\mathrm{~kg} / \mathrm{km}^{2}\end{array}$ \\
\hline Crête & 6.3 & 0.9 & 5.4 & 0.48 & 2.39 & 117 \\
\hline Dye 371 & 4.5 & 0.5 & 4.0 & 0.53 & 1.93 & 95 \\
\hline Dye 380 & 6.0 & 0.5 & 5.5 & 0.39 & 1.98 & 97 \\
\hline Milcent & 6.3 & 0.8 & 5.5 & 0.68 & 3.46 & 170 \\
\hline $\mathrm{CC}$ & 4.6 & 0.6 & 4.0 & 0.35 & 1.27 & 63 \\
\hline Byrd & 4.2 & 0.9 & 3.3 & 0.15 & 0.45 & 22 \\
\hline SP 1883 & 2.7 & 1.2 & 1.5 & 0.16 & 0.22 & 11 \\
\hline SP 1816 & 8.8 & 1.3 & 7.5 & 0.25 & 1.68 & 83 \\
\hline SP 1259 & 11.4 & 1.2 & 10.2 & 0.20 & 1.84 & 90 \\
\hline RISP J-9 & 4.2 & 1.7 & 2.5 & 0.14 & 0.32 & 16 \\
\hline
\end{tabular}




\begin{tabular}{|c|c|c|c|c|c|}
\hline \multicolumn{2}{|c|}{$\begin{array}{l}\text { Latitude } \\
\text { of injection }\end{array}$} & $\begin{array}{l}\text { Year of } \\
\text { injection }\end{array}$ & Greenland & Antarctica & $\mathrm{R}$ \\
\hline $\begin{array}{l}75^{\circ} \mathrm{N} \\
11^{\circ} \mathrm{N}\end{array}$ & $\begin{array}{l}\text { total } \beta \\
\mathrm{mCi} / \mathrm{km}^{2}\end{array}$ & $\begin{array}{c}1961-62 \\
1952,1954\end{array}$ & $\begin{array}{r}15.3 \\
3.2\end{array}$ & $\begin{array}{l}2.6 \\
2.2\end{array}$ & $\begin{array}{l}5.9 \\
1.45\end{array}$ \\
\hline $\begin{array}{l}8^{\circ} \mathrm{S} \\
?\end{array}$ & $\begin{array}{l}\mathrm{H}_{2} \mathrm{SO}_{1} \\
\mathrm{~kg} / \mathrm{km}^{2}\end{array}$ & $\begin{array}{c}1815 \\
\text { " } 1259 "\end{array}$ & $\begin{array}{r}64 \\
106\end{array}$ & $\begin{array}{l}83 \\
90\end{array}$ & $\begin{array}{l}0.77 \\
1.18\end{array}$ \\
\hline
\end{tabular}

(A.D. 1783) deposited $137 \mathrm{~kg} / \mathrm{km}^{2}$ in the Crête region (Clausen and Hammer 1988, this volume). In the South Pole region, the Tambora eruption deposited $83 \mathrm{~kg} / \mathrm{km}^{2}$, some eight times more than that deposited by the Krakatoa eruption $\left(11 \mathrm{~kg} / \mathrm{km}^{2}\right)$, which is similar to the natural background of $8 \mathrm{~kg} / \mathrm{km}^{2}$ during the time of volcanic deposition.

\section{Latitude of 1259 eruption}

To estimate the site of the A.D. 1259 eruption, we compare the $\mathrm{H}_{2} \mathrm{SO}_{4}$ deposition from known volcanic eruptions with the deposition of the total $B$ activity from atmospheric nuclear-bomb tests. We assume a uniform global deposition pattern of volcanic-acid gases from large volcanic eruptions and of the debris produced by atmospheric nuclear tests if occurring at the same latitude. At present we know of three well-documented global events which are clearly recognized as index horizons for the entire Greenland and Antarctic ice sheets:

the Tambora eruption at $8^{\circ} \mathrm{S}$ in 1815 ,

the American bomb tests at $11^{\circ} \mathrm{N}$ in 1952 and 1954,

the Russian bomb tests at $75^{\circ} \mathrm{N}$ in 1961 and 1962 (UNSCEAR Report 1982). Table IV lists data for these events. Greenland is represented by Dye 3 and Crête, and Antarctica by South Pole, because ice cores from these regions have been analyzed both for anions from the three major volcanic eruptions ("1259", Laki and Tambora) and for total $B$ activity from the Russian and American atmospheric bomb-test series.

The total $\beta$ values are given in deposition of $\mathrm{mCi} / \mathrm{km}^{2}$, originating from a total $\beta$ injection of 22.6 and $9.6 \mathrm{MCi}$ $\left({ }^{90} \mathrm{Sr}+{ }^{137} \mathrm{Cs}=\right.$ "total $\left.B^{\prime \prime}\right)$ at $75^{\circ}$ and $11{ }^{\circ} \mathrm{N}$ respectively (Clausen and Hammer 1988, this volume). $\mathrm{R}$ is the ratio between the depositions in Greenland and Antarctica. In Figure 10, $\mathrm{R}$ is plotted on a semi-logarithmic scale as a function of the latitude of the site of injection. This figure suggests that the "1259" volcano was most likely to be located close to the Equator, probably in the Northern Hemisphere.

Total volcanic amount of $\mathrm{H}_{2} \mathrm{SO}_{4}$

Combining the deposition of the total $B$ activity originating from the $9.6 \mathrm{MCi}$ injected at low northern latitude in 1952 and 1954 (column 4, Table V) with the deposition of volcanic $\mathrm{H}_{2} \mathrm{SO}_{4}$ (column 3, Table V), we calculate in Table $\mathrm{V}$ the total amount of $\mathrm{H}_{2} \mathrm{SO}_{4}$ injected

TABLE V. MAGNITUDE OF THE VOLCANIC ERUPTIONS.

\begin{tabular}{|c|c|c|c|c|c|}
\hline $\begin{array}{l}1 \\
\text { Year } \\
\text { of max. } \\
\text { deposit }\end{array}$ & $\begin{array}{c}2 \\
\text { Site }\end{array}$ & $\begin{array}{l}\quad 3 \\
\text { Volc. } \mathrm{H}_{2} \mathrm{SO}_{1} \\
\mathrm{~kg} / \mathrm{km}^{2}\end{array}$ & $\begin{array}{l}\stackrel{4}{\text { Total B }} \\
\mathrm{mCi} / \mathrm{km}^{2}\end{array}$ & $\left(\begin{array}{c}\frac{5}{9.6 \mathrm{MCi}} \\
\underset{\times 10^{9}}{\text { Total } \beta^{\prime \prime}}\end{array}\right.$ & $\begin{array}{c}6 \\
\mathrm{H}_{2} \mathrm{SO}_{4} \\
10^{6} \text { tons }\end{array}$ \\
\hline 1259 & $\begin{array}{l}\text { Crête } \\
\text { Dye } 3 \\
\text { Milcent } \\
\text { CC } \\
\text { Byrd } \\
\text { J-9 } \\
\text { South Pole }\end{array}$ & $\begin{array}{r}117 \\
96 \\
170 \\
63 \\
22 \\
16 \\
90\end{array}$ & $\begin{array}{l}3.36 \\
3.02 \\
4.79 \\
2.87 \\
0.89 \\
0.58 \\
2.19\end{array}$ & $\begin{array}{r}2.86 \\
3.18 \\
2.00 \\
3.35 \\
10.79 \\
16.55 \\
4.38\end{array}$ & $\begin{array}{l}335 \\
305 \\
340 \\
211 \\
237 \\
265 \\
394\end{array}$ \\
\hline $1884-85$ & South Pole & 11 & 2.19 & 4.38 & 48 \\
\hline 1816 & $\begin{array}{l}\text { South Pole } \\
\text { Crête } \\
\text { Dye } 3\end{array}$ & $\begin{array}{l}83 \\
69 \\
59\end{array}$ & $\begin{array}{l}2.19 \\
3.36 \\
3.02\end{array}$ & $\begin{array}{l}4.38 \\
2.86 \\
3.18\end{array}$ & $\begin{array}{l}364 \\
197 \\
188\end{array}$ \\
\hline
\end{tabular}

into the atmosphere (column 6). Column 5 shows that the $9.6 \mathrm{MCi}$ (e.g. at Crête) is equal to $2.86 \times 10^{9}$ times the total $\beta$ deposition per $\mathrm{km}^{2}$.

The total amount of $\mathrm{H}_{2} \mathrm{SO}_{4}$ in the 1259 eruption was some $300 \times 10^{6}$ tons, with the mean value $(298 \pm 60) \times 10^{6}$ and $(299 \pm 84) \times 10^{6}$ tons for Greenland and Antarctic sites respectively (column 6, Table V). The individual values vary by less than a factor of 2 , and the coefficients of variations in the Greenland and Antarctic mean values are 20 and $30 \%$ respectively. This scatter is easily explained by drift-snow (sastrugi) noise, which in Greenland typically results in accumulation-series noise of

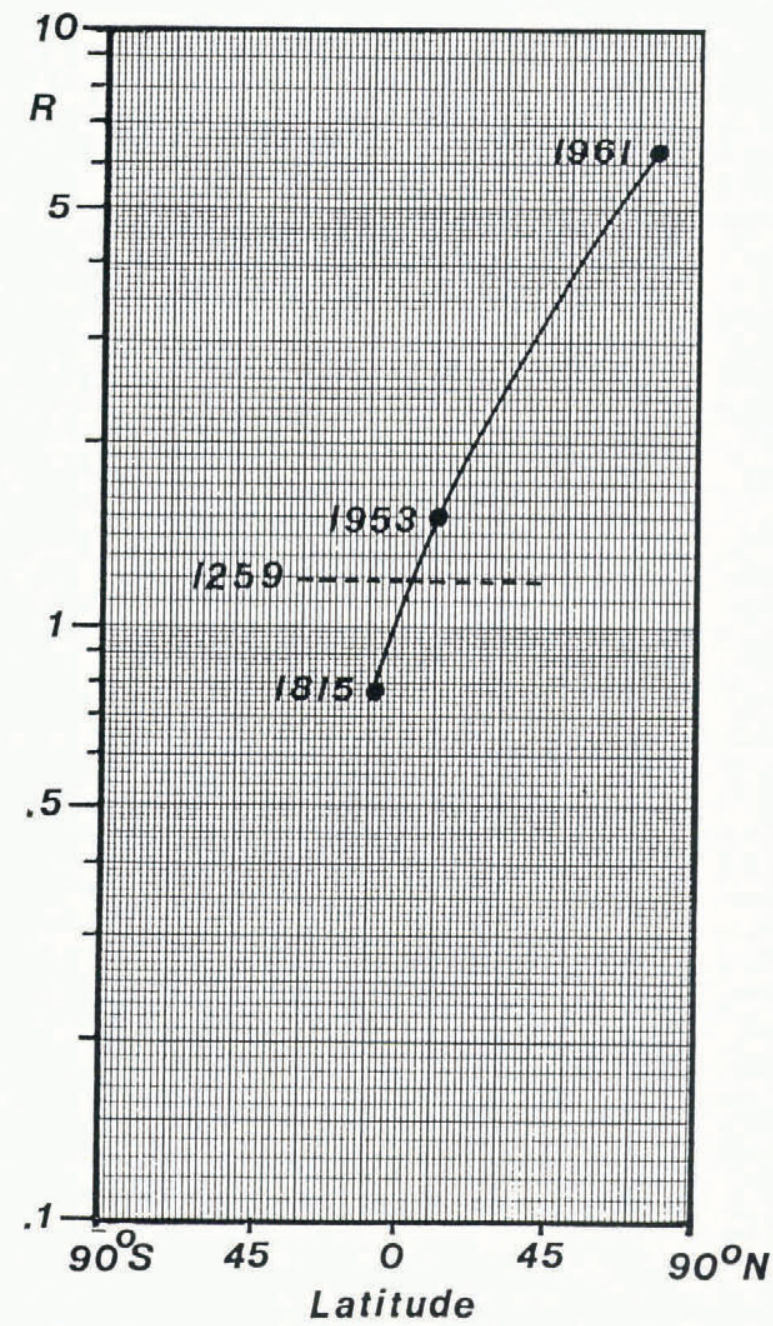

Fig.10 shows on a semi-logarithmic scale the ratio $\mathrm{R}$ from Table IV (between the depositions in Greenland and Antarctica) of injections (total $\beta$ activity from nuclear-bomb tests and strong acids from the Tambora eruption) into the atmosphere as a function of the site of injection (degree latitude). 1961, 1953 and 1815 refer to the $1961-62,1952$ and 1954 atmospheric bomb-test series and to the 1815 Tambora eruption respectively. $\mathrm{R}$ of the A.D. 1259 event (dotted line) corresponds to a site of eruption close to the Equator in the Northern Hemisphere. 
about $40 \%$ of the yearly value (Fisher and others 1985). In regions with a low rate of annual accumulation this kind of noise increases. The Tambora and the "1259" event are comparable in magnitude, and Krakatoa is one order of magnitude smaller. The Greenland values of the Tambora eruption are from Clausen and Hammer 1988 (this volume).

The calculation of the magnitude of the Tambora eruption at $8^{\circ} \mathrm{S}$, based on the Greenland total $\beta$ deposition from a low northern-latitude test site, will probably underestimate the total $\mathrm{H}_{2} \mathrm{SO}_{4}$ production, because the volcano is located south of the Equator and the total $\beta$ was injected into the atmosphere north of the Equator. In a similar way the calculation based on Antarctic values has probably overestimated the production of the $\mathrm{H}_{2} \mathrm{SO}_{4}$, suggesting a total $\mathrm{H}_{2} \mathrm{SO}_{4}$ production similar to that of the 1259 event, some $300 \times 10^{6}$ tons.

\section{CONCLUSION}

A major volcanic eruption in A.D. 1259, close to the Equator in the Northern Hemisphere, injected some $300 \times 10^{6}$ tons of sulphuric acid into the atmosphere. This volcanic eruption is one of the largest which has occurred in the last 10000 years, of the same magnitude as the Tambora 1815 eruption, and serves as a distinct interhemispheric index horizon for the dating of ice cores.

\section{ACKNOWLEDGEMENTS}

Part of this study was performed while $\mathrm{H}$ B Clausen spent 3 months as Visiting Professor in the Ice Core Laboratory at the State University of New York at Buffalo. Thanks are given to $\mathrm{K}$ Azuma, who performed the laboratory chemical analyses, and to the Commission for Scientific Research in Greenland, the European Economic Communities (contract CLI-067 DK $(G)$ ) and to the U.S. National Science Foundation, Division of Polar Programs, for financial support of the laboratories in Buffalo and Copenhagen.

\section{REFERENCES}

Bender J A, Gow A J 1961 Deep drilling in Antarctica. International Association of Scientific Hydrology Publication 55 (General Assembly of Helsinki 1960 - Symposium on Antarctic Glaciology): 132-141

Boutron C 1979 Alkali and alkaline earth enrichments in aerosols deposited in Antarctic snows. Atmospheric Environment 13(7): 919-924

Chiang E, Langway C C Jr 1978 Antarctic ice core recovery. Antarctic Journal of the United States 13(4): 59-61

Clausen H B, Dansgaard W 1977 Less surface accumulation on the Ross Ice Shelf than hiterhto assumed. International Association of Hydrological Sciences Publication 118 (General Assembly of Grenoble 1975-Isotopes and impurities in Snow and Ice): 172-176

Clausen H B, Hammer C U 1988 The Laki and Tambora eruptions as revealed in Greenland ice cores from 11 locations. Annals of Glaciology 10: 16-22

Dansgaard W, Johnsen S J, Clausen H B, Langway C C Jr 1971 Climatic record revealed by the Camp Century ice core. In Turekian $\mathrm{K}$ K (ed) Late Cenozoic glacial ages. New Haven, CT, and London, Yale University Press: $37-57$

Finkel R C, Langway C C Jr, Clausen H B 1986 Changes in precipitation chemistry at Dye 3, Greenland. Journal of Geophysical Research 91(D9): 9849-9855

Fisher D A, Koerner R M 1988 The effects of wind on $\delta\left({ }^{18} \mathrm{O}\right)$ and accumulation give an inferred record of seasonal $\delta$ amplitude from the Agassiz Ice Cap, Ellesmere Island, Canada. Annals of Glaciology 10: 34-37

Fisher D A, Reeh N, Clausen H B 1985 Stratigraphic noise in time series derived from ice cores. Annals of Glaciology 7: 76-83

Gow A J, Blander F de, Crozaz G, Picciotto E 1972 Snow accumulation at "Byrd" Station, Antarctica. Journal of Glaciology 11(61): 59-64

Gundestrup N S, Johnsen S J, Reeh N 1984 ISTUK - a deep ice core drill system. US Army Corps of Engineers. Cold Regions Research and Engineering Laboratory. Special Report 84-34: 7-19
Hammer C U 1980 Acidity of polar ice cores in relation to absolute dating, past volcanism and radio-echoes. Journal of Glaciology 25(93): 359-372

Hammer C U 1984 Traces of Icelandic eruptions in the Greenland ice sheet. Jökull 34: 51-65

Hammer C U, Clausen H B, Dansgaard W, Gundestrup N, Johnsen S J, Reeh N 1978 Dating of Greenland ice cores by flow models, isotopes, volcanic debris and continental dust. Journal of Glaciology 20(82): 3-26

Hammer C U, Clausen H B, Dansgaard W 1980 Greenland ice sheet evidence of post-glacial volcanism and its climatic impact. Nature 288(5788): 230-235

Hammer C U, Clausen H B, Langway C C Jr 1985 The Byrd ice core: continuous acidity measurements and solid electrical conductivity measurements. Annals of Glaciology 7: 214

Hammer C U, Clausen H B, Tauber H 1986 Ice-core dating of the Pleistocene/Holocene boundary applied to a calibration of the ${ }^{14} \mathrm{C}$ time scale. Radiocarbon $28(2 \mathrm{~A})$ : 284-291

Herron M M 1982 Impurity sources of $\mathrm{F}^{-}, \mathrm{Cl}^{-}, \mathrm{NO}_{3}^{-}$and $\mathrm{SO}_{4}{ }^{2-}$ in Greenland and Antarctic precipitation. Journal of Geophysical Research 87(C4): 3052-3060

Herron M M, Langway C C Jr 1979 Dating of Ross Ice Shelf cores by chemical analysis. Journal of Glaciology 24(90): $345-357$

Herron M M, Langway C C Jr, Weiss $\mathrm{H} \mathrm{V}$, Cragin $\mathrm{J} \mathrm{H}$ 1977 Atmospheric metals and sulfate in the Greenland ice sheet. Geochimica et Cosmochimica Acta 41: 915-920

Lambert G, Ardouin B, Sanak J, Lorius C, Pourchet M 1977 Accumulation of snow and radioactive debris in Antarctica: a possible refined radio chronology beyond reference levels. International Association of Hydrological Sciences Publication 118 (General Assembly of Grenoble 1975-Isotopes and Impurities in Snow and Ice): 146-158

Langway C C Jr, Oeschger H, Dansgaard W (eds) 1985 Greenland ice core: geophysics, geochemistry and the environment. Washington, DC, American Geophysical Union (Geophysical Monograph 33)

Mayewski P A and 7 others 1986 Sulfate and nitrate concentrations from a south Greenland ice core. Science 232(4753): 975-977

Mosley-Thompson E, Thompson L G 1982 Nine centuries of microparticle deposition at the South Pole. Quaternary Research 17(1): 1-13

Rasmussen K L, Clausen H B, Risbo T 1984 Nitrate in the Greenland ice sheet in the year following the 1908 Tunguska event. Icarus 58: 101-104

Schwander J Unpublished Lufteinschluss im Eis in Grönland und der Antarktis. Messung der elektrischen Leitfähigkeit von Eisproben für klimatologische Andwendungen. ( $\mathrm{PhD}$ thesis, Universität Bern, 1984)

Simkin T, Siebert L, McClelland L, Bridge D, Newhall C, Latter J H 1981 Volcanoes of the world. Washington, DC, Smithsonian Institution

Ueda H T, Garfield D E 1968 Drilling through the Greenland ice sheet. CRREL Special Report 126

Ueda H T, Garfield D E 1969 Core drilling through the Antarctic ice sheet. CRREL Technical Report 231

United Nations Scientific Committee on the Effects of Atomic Radiation 1982. Ionizing radiation: sources and biological effects. Report to the General Assembly, with annexes. New York, United Nations, Annex E: 211-248

Zanolini F, Delmas R J, Legrand M 1985 Sulphuric and nitric acid concentrations and spikes along a $200 \mathrm{~m}$ deep ice core at D 57 (Terre Adélie, Antarctica). Annals of Glaciology 7: 70-75 